\title{
Klientský systém a ukrajinská pracovní migrace do České republiky
}

\section{Clientalist System and Ukrainian Labour Immigration to the Czech Republic}

\author{
Michal Nekorjak
}

ABSTRACT Labour migration from the Ukraine into the Czech Republic has been underway for fifteen years. Throughout this time period the Ukrainians have developed several strategies which provide them with access to the Czech labour market. One of these strategies is participating in an organized system called "clientalism" which among the others occupies a dominant role. The clientalist system is in terms of power and income hierarchized into three stages. At the top of an imaginary pyramid there are groups of organized crime, at the bottom Ukrainian workers. There is a third group standing between these two: so-called clients. Their main activity is mediation. They transfer money between the mafia and immigrants, act as mediators between supply and demand for workforce on the labour market and last but not least they mediate a contact between immigrants and both Czech and Ukrainian bureaus. My intention is to describe the clientalist system, interpret its functions and the reasons why it is established in a given form.

KEY WORDS clientalist system, immigration, international migration, social exclusion, Ukrainia

Neznám recept, jak to dneska zlepšit... Český stát to může udělat během jednoho měsíce, ale stát to nechce. Nevím, proč na tom nemají zájem.

Citát pochází z rozhovoru s ukrajinským diplomatem. Problémy krajanů spojené s pracovní migrací se staly součástí jeho práce a z tohoto důvodu vstupoval i do jednání s českými úrady i představiteli státní moci. Měl tedy o celé problematice dobrý přehled a samozřjmě na ní měl i svůj názor. V této stati recept na to, ,jak to dneska zlepšit“, hledat nebudeme. Ten by měli najít jiní, najdou-li k tomu dostatek dobré vůle. Sociální věda jim k tomu může předat jen své interpretace a vysvětlení.

Tato stat' vychází z poznatků tř́letého kvalitativního výzkumu ukrajinské pracovní migrace směřující do České republiky. Ve výzkumu se našimi partnery v rozhovorech, kromě ukrajinských dělníků, stalo pět „klientů“, jeden člen mafie, pět českých policistů a devět

Sociální studia. Fakulta sociálních studií Masarykovy univerzity, 1/2006. S. 89-109. ISSN 1214-813X.

Tato stat' vznikla v dubnu 2006 s podporou Ministerstva školství, mládeže a tělovýchovy - výzkumný záměr „Reprodukce a integrace společnosti““(MSM002 1622408). 
zaměstnavatelů. ${ }^{1}$ Výzkum také probíhal dvakrát na západní Ukrajině, v prostředí, ze kterého k nám prrichází nejvíce pracovních imigrantů. ${ }^{2}$

\section{Vyjasnění pojmu}

Slovem klient se označuje zákazník či chráněnec. V kontextu ukrajinské migrace označuje tento termín člověka, který organizuje ukrajinskou pracovní sílu a za účelem vlastního výdělku ji nabízí na českém pracovním trhu. Na první pohled má zdánlivě nelogický, poněkud matoucí význam. Klientem by přece měl být ten, kdo usiluje o to vydělat si peníze v zahraničí a k tomuto účelu využije nabídky služeb zprostředkovatelů práce, oněch ,klientů“. Za logikou zjevnou se ale skrývá ještě jedna: logika vztahů organizovaného zločinu, který na pracovní migraci Ukrajinců také participuje. A to tak významně, že byl schopen své označení, svou logiku, ,vnutit“ i ostatním. I těm, kteří o vazbách na organizovaný zločin nevědí nic, nebo o nich mají jen mlhavé představy. Označení klient je běžně používáno nejen samotnými Ukrajinci, ale i odborníky, kteří o ukrajinských imigrantech píší (viz například Černík a kol. 2005, Leontiyeva 2005), policisty a českými zaměstnavateli.

Klienti, to se př́mo mezi poldama takhle říká, protože to takhle ti Ukrajinci nazývají.

(pan W., policista)

Toto označení používají i média (viz Leschtina 2005), dostalo se do obecného povědomí lidí, kteří se ukrajinskou migrací hlouběji nezabývají. Zda ale bude jednou ve slovníku spisovné češtiny u hesla klient popsán i tento jeho nový význam, to nevím. Zdá se, že český stát se rozhodl s tzv. „klienty“" skoncovat. ${ }^{3}$

V následujícím textu bych se termínu klient rád vyhnul. Nejde o demonstrativní, křečovitou hygienu ducha, který nechce přijmout logiku označování pocházející ze světa organizovaného zločinu. Je to proto, že se jedná o zavádějící pojem, který je př́lišs úzký. Označuje jen jeden typ vztahů (mafie a její klienti) a druhý opomíjí (,klient“‘ a jeho klient-dělník). Navíc je toto označení eufemismem, protože zakrývá i částečně násilnou a nedobrovolnou povahu vztahů mezi mafií a „klienty“.

Používanou alternativou je slovo zprostředkovatel či prostředník (viz například Výzkum obchodu s lidmi 2005, Drbohlav a Šelepová 2001). Ovšem ani to není vhodné označení. V prostředí mezinárodní migrace se jím běžně míní osoba, která pomáhá imigrantům najít práci, př́ípadně sehnat potřebná povolení, osoba, která stojí často na startu pracovní migrace.

Tento člen mafie byl řadovým pěšákem, výběrčím peněz, tzv. racketeerem.

2 Na počátku výzkumu byly rozhovory vedeny volně. Až po základním zmapování problematiky jsem vytvořil sadu otázek zaměřených na konkrétní problémy. Časem se ukázala nutnost provést rozhovory i s českými zaměstnavateli, policisty a úředníky. Mezi imigranty jsem nevyhledával náhodné kontakty, ale vždy jsem se na ně obracel na základě osobních kontaktů a doporučení. Pobyt na Zakarpatsku mi umožnil poznat životní podmínky Ukrajinců a jejich strategie zvládání ekonomického nedostatku, mezi nimiž je emigrace jen jednou z vícera nabízených možností.

3 Viz doporučení z Výzkumu obchodu s lidmi... (2005), který se stal podkladem pro formulování Národni strategie... (2005) zpracované ministerstvem vnitra. 
Ukrajinský zprostředkovatel ale běžně vykonává celou řadu dalších činností, které ještě zmíníme. Může svými službami provázet migranta po celou dobu pobytu až po jeho návrat domů, jejich vztah je spišš skutečně klientský. I na Ukrajině existují klasičtí zprostředkovatelé či agentury vyhledávající zájemce o legální zaměstnání v Česku. Ti však nedohlíží na průběh pobytu v zahraničí a pokud nezaměstnávají zájemce př́mo v českých firmách, předávají migranty právě „klientům“. ${ }^{4}$

Slovo klient budu tedy uvozovat, budu-li mít na mysli onen střední článek v klientském systému, stojící mezi dělníky a mafiemi. Naopak již zavedené sousloví klientský systém ponechám bez úprav a nebudu jej uvozovat, protože se nevztahuje pouze na „klienty“, ale zahrnuje širší škálu vztahů.

\section{První stupeň klientského systému aneb adaptační strategie}

Klientský systém tvoří dva základní stupně mocensky nerovných vtahů a tři typy aktérů. Na vrcholu pomyslné pyramidy moci stojí organizovaný zločin - ukrajinská mafie. Na spodním stupni jsou imigranti, kteří celý systém sytí ekonomickými prostředky - svou mzdou. Mezi těmito dvěma skupinami, jako hlavní mediátoři, stojí „klienti“. Pro mafii jsou hlavními partnery a jejich vztah jsem označil za druhý stupeň klientského systému. Vztah mezi imigrantem-pracovníkem a „klientem“ jsem označil za stupeň první. ${ }^{5}$

Kromě toho, že se obě roviny liší podle typů hlavních aktérů a že obě vznikly za jiných okolností (viz další text), má smysl důsledně rozlišovat oba stupně ještě ze dvou důvodů. Na našem území vznikl první stupeň klientského systému historicky dř́ve, mafie se do celého procesu pracovní migrace zapojila až později. Zadruhé, participaci mafíi v tomto systému lze chápat jako jakousi nástavbu. Druhý stupeň, který reprezentuje vztah mafií a „klientư“, by bez prvního nefungoval. Naopak první stupeň by se bez vměšování mafií obešel, tak jako se bez něho obešel na počátku,v době svého vzniku.

$4 \quad$ Někteří zprostředkovatelé nabízejí pracovní místa v Čechách podvodně. Vyberou peníze za provize a nejrůznější organizační náklady (doprava, víza) a pak zmizí. Jindy zase inzerované podmínky neodpovídají realitě (mzdy, pracovní zařazení či podmínky ubytování apod.). V jistém smyslu tedy může být kontakt se zprostředkovateli rizikovější než vstup na český trh práce pomocí „klientů“, kteří zůstávají v kontaktu se svými zaměstnanci po celou dobu pobytu.

5 Celý článek je zaměřen primárně na ukrajinské imigranty. Je třeba podotknout, že v klientském systému participují i občané z jiných zemí. Mezi „klienty“ se objevují zejména čeští občané. Během výzkumu jsem zaznamenal čtyři typy těchto „klientů“: (1) ukrajinské „klienty“, kteří získali české občanství; (2) v Česku narozené české občany, jejichž rodiče pochází z dnešního území Ukrajiny; (3) české občany, kteří uzavřeli sňatek s ukrajinským občanem; (4) české občany, kteří dělají „klienty“ s ukrajinskými společníky. Nikdo z mnou zaznamenaných typů nevstoupil do klientského systému „Zvenčí“, bez kontaktů na tradiční ukrajinské „,klienty“.

Mezi dělníky v klientském systému lze najít i občany z dalších postsovětských zemí, zejména z Moldavska a Běloruska. S těmito typy cizinců jsem se ale během výzkumu setkal jen výjimečně, osobně jsem hovořil pouze se dvěma: s dělníkem z Běloruska a s „klientem“ deklarujícím českou národnost pracujícím s ukrajinským společníkem. 
„Klienti“ se začali objevovat poměrně brzy po zahájení nové vlny emigrace z Ukrajiny do České republiky po roce $1991 .{ }^{6}$ Zpočátku byl klientský systém jednostupňový a mafie v něm žádnou speciální úlohu neměly.

Tehdy tam ta mafie v tom ještě nebyla... Ta se nacpala až postupně.

(pan T., ,klient"“)

Roli „klientư“ přijímali často předáci part či obyčejní dělníci, kteří se dokázali v novém prostředí zorientovat a chopit se nových příležitostí. Postupně se role „klientü“ profesionalizovala a institucionalizovala skrze legálně provozované firmy. Ti nejúspěšnější dnes obstarávají práci pro stovky imigrantů. Kontrolují je pomocí tzv. podklientů, managerů, kteř́ jsou částečně samostatní a vykonávají dohled na místě práce. ${ }^{7}$

Konkrétní podobu prvního stupně klientského systému považuji za výsledek adaptační strategie imigrantů na podmínky českého trhu práce a na jejich formální postavení, tedy na různé soubory práv a povinností, které jsou cizincům přiděleny. Důležitou roli v procesu migrace hrají rovněž sociální sítě - tedy sociální kapitál. V menší míře se v odborné literatuře hovoří o kulturním kapitálu, přestože jde o koncept, jenž zahrnuje další běžně zmiňované kompetence podstatné pro zvládání každodennosti v cizím prostředí: schopnost se $\mathrm{v}$ něm zorientovat a porozumět jazyku, tedy disponovat (vhodným) věděním. Ve stručnosti popíšeme všechny tři zmíněné oblasti: (a) formální postavení cizinců v Česku, (b) roli sociálního a kulturního kapitálu a (c) podmínky na trhu práce. ${ }^{8}$

Všechny tyto okolnosti zásadním způsobem přispěly ke vzniku dalších strategií, které Ukrajinci na našem trhu práce uplatňují. Zapojení do klientského systému je jen jednou z nich. Míru uplatnění této strategie ale můžeme pouze odhadovat, protože spolehlivá data neexistují. Na základě svých poznatků a mínění samotných imigrantů můžeme formulovat jen předběžnou pracovní hypotézu, že zkušenost s participací v klientském systému má čtyřicet až padesát procent imigrantů z Ukrajiny.

\section{Formální postavení cizinců: stratifikace práv, ilegální a kvazi-legální status}

Legislativa vytváŕí různé kategorie cizinců, které jsou nadány rozdílnými právy a povinnostmi. V odborné literatuře se tato diferenciace analyzuje a srovnává např́klad pomocí konceptu občanské stratifikace (Morris 2002: 103). Princip rozdělování populace na území národního státu do různých statusových skupin podle státního občanství lze

$6 \quad$ Ukrajinci do českých zemí migrovali v minulosti v několika vlnách (Zilynskyj 1995, Zilynskyj a Kočík 2001). V tomto smyslu není současný př́liv Ukrajinců novým jevem.

7 Co do velikosti jejich pracovních skupin existují mezi „klienty“ značné rozdíly. Od malých „klientư“, pod něž nespadá více jak deset lidí, až po vlastníky skutečně rozsáhlých sítí čítajících přes tisíc imigrantů.

8 Tento výzkum nedokáže odpovědět na to, zda lze jednu z těchto tř́ okolností označit pro institucionalizaci klientského systému za klíčovou. Zastávám hypotézu, že se jedná o vzájemnou souhru těchto podmínek a že je lze jen obtížně hierarchizovat. 
považovat za univerzální. Ale jednotlivé země mají rozdílné legislativy, a tudíž vytvářejí i odlišné statusové skupiny - jak z hlediska států původu přistěhovalců, tak z hlediska uznaných práv.

Stratifikace obyvatelstva podle občanství odráží snahy národních států regulovat migraci a také různost představ o žádoucí míře inkluze cizinců do domácí populace. Překážky kladené cizincům lze chápat jako preventivní opatření zabraňující jejich trvalému usazení (tamtéž). Český stát použivá tř̌ formální úrovně ochrany: reguluje vstup na české území pomocí viz, dalším prahem je udělování povoleni k pobytu a jako přímá ochrana pracovního trhu je využívána instituce povolení $k$ zaměstnání. Na jednotlivých typech povolení se podílejí různé státní instituce. Víza udělují diplomatické mise $\mathrm{v}$ zahraničí, povolení $\mathrm{k}$ pobytu cizinecká policie, povolení $\mathrm{k}$ zaměstnání úř́ady práce. Pro formování strategií imigrantů na trhu práce je důležité, že zákony v České republice diferencují cizince ze dvou hlavních hledisek: podle země pưvodu a podle účelu pobytu.

$\mathrm{Z}$ hlediska země původu záleží na tom, zda cizinec zamýšlející pracovat v Česku potřebuje či nepotřebuje vstupní víza. Například občané Evropské unie, Švýcarska a dalších zemí víza nepotřebují. Země, jejichž občané víza potřebují, lze ještě rozdělit podle toho, zda jsou víza udělována bez větších problémů (například Kanada, USA), či zda bývá udělování víz podrobeno obstrukcím a prověřování žadatelů (Ukrajina, Vietnam, Rusko, Čína...). Obecně platí, že do první skupiny se řadí země ekonomicky rozvinuté a politicky stabilní, do kategorie druhé se řadí země ekonomicky slabší, politicky nestabilní či s režimem, který je považován českou politickou reprezentací za nepřátelský či rizikový. Země původu u cizinců ještě rozhoduje o tom, zda potřebují nebo nepotřebují povolení k pobytu, pokud se rozhodli, že budou v Česku vydělávat peníze.

Druhým podstatným hlediskem je účel pobytu cizince. Pro občany z nejvíce znevýhodněných zemí (např́klad Ukrajina, Vietnam) je podstatné, že zákony stanoví jiná pravidla pro podnikatele a živnostníky a jiná pro zaměstnance. Na podnikání a zakládání živností se nevztahují v podstatě žádné výjimečné regulace. Práva a povinnosti cizincủ živnostníků a podnikatelů jsou formálně stejná jako práva a povinnosti českých občanů. Politika státu směřuje k podpoře podnikání a živností nejen kvůli ekonomickému rozvoji: podnikatelé a živnostníci jsou institucemi sociálního státu chráněni méně než zaměstnanci, a tudíž neodčerpávají ze státní kasy tolik finančních prostředků. Pojištění si platí sami a podstupují větší rizika; jejich kompenzací je hypotetická možnost větších zisků. V případě uzavírání zaměstnaneckých kontraktů se cizinci dostávají pod částečnou ochranu státu a participují na sociální solidaritě hostitelské společnosti, byt' jsou jejich práva omezena. ${ }^{9}$ Ve srovnání s živnostenským listem je ale vyřízení povolení $\mathrm{k}$ zaměstnání obtížnější. Do procesu povolování zasahují úruady práce, které mají při uzavření kontraktu poslední slovo, protože musí posoudit aktuální situaci na pracovním trhu a při obsazování volných míst mají za úkol dbát na přednostní umístění českých občanů hledajících práci.

9 Míra přiznaných práv se odvíjí od typu pobytu. Většina ukrajinských imigrantů zde pobývá na tzv. dlouhodobá víza, a tudíž ze zákona nemají nárok na sociální dávky a pomoc v nezaměstnanosti. Mohou však například využívat instituce zdravotního pojištění či později část důchodu čerpat z Česka. 
Kromě formálních pravidel je třeba zohlednit tzv. neformální dimenzi občanské stratifikace (tamtéž: 147). V praxi jsou formálně přidělená práva posilována nebo naopak omezována v konkrétních sociálních interakcích, které jsou založeny na individuálních interpretacích a postojích státních úředníků. V této souvislosti je třeba brát v úvahu, že Ukrajinci patř́ v Česku dlouhodobě k nejméně pozitivně hodnoceným národnostem (viz např́iklad Náš vztah ..., 2005). I v našich rozhovorech zmiňovali někteří respondenti neformální překážky, se kterými se setkali při jednání s úředníky.

Jih Čech to je strach tam jít, tam jsou konzervativní (úředníci). ${ }^{10} \mathrm{~V}$ Budějovicích nám bylo řečeno, že žádný Ukrajinec nemá kladný rozhodnutí a nebude mít pracovní povolení. Mluvil jsem s podnikatelem (českým) a tomu řekli na úřadu práce, že si budou chránit svoji zemi. Úřad práce v Budějovicích nám řekl, že nevydají žádný pracovní povolení, at’ si berou Češi Cikány.

(pan B., ,klient“)

Budějovicko patří mezi regiony s vůbec nejnižší mírou nezaměstnanosti, přesto má mezi některými imigranty pověst místa, kde lze získat pracovní povolení jen obtížně. Podobně je např́kklad Táborsko pověstné př́isným přístupem cizinecké policie. Přestože všude platí stejné formální zákony, mají imigranti v různých regionech různé zkušenosti, které nelze vysvětlit pomocí cílené regulace trhu práce $\mathrm{v}$ závislosti na nezaměstnanosti v regionu, jak stanoví zákon.

Spletitost právních překážek stavěných ukrajinským imigrantům do cesty jsem výše načrtl jen v obrysech. Ve skutečnosti je celý systém formálních prahů složitější. Obtížná dostupnost víz, povolení k pobytu a k zaměstnání a neformální překážky mají na strategie Ukrajinců tento vliv:

(1) Ukrajinci využívají služeb agentur, prostředníků nebo „klientư“, kteří jim víza a ostatní povolení obstarají. Pro tyto aktéry jsou doklady dostupnější kvůli jejich sociálnímu a kulturnímu kapitálu, díky tomu, že se vyznají v předpisech a vědí, na koho se obrátit. Pro imigranty se jedná o pragmatickou volbu:

Budu dva měsíce chodit okolo po úřadech a nic neudělám, práci ani dokumenty.

(pan P., dělník)

(2) Namísto legálního pobytu volí mnohdy imigranti druhou alternativu, nelegální pobyt. $\mathrm{V}$ roce 2004 žilo na našem území podle statistik 80000 Ukrajinců (Cizinci..., 2005). Byt' nejsou přesnější údaje oficiálně známy, odhady hovoří o tom, že zde ilegálně pobývá dalších sto tisíc přistěhovalců z Ukrajiny (Zpráva..., 2004; Výzkum obchodu..., 2005). Je běžné přicestovat do Česka na krátkodobé, tzv. turistické vízum a začít zde nelegálně pracovat. Poprrípadě po získání všech standardních povolení a př́islušného víza začít pracovat legálně, ale svůj legální status po roce změnit tím, že povolení nebudou obnovena. Výsledek vyřizování žádostí je totiž vnímán jako nejistý a nákladný z hlediska času i peněz: ${ }^{11}$

10 Uvnitř citací budu do závorek vkládat vysvětlující poznámky, protože ne vždy je kontext sdělení zřejmý.

11 Náklady se liší, vyřízení dokladů přijde průměrně na 300-800 amerických dolarů - záleží na paletě služeb, které mají pokrýt. Zahrnují jak náklady na legální operace, tak náklady na úplatky a na pokrytí zisku zprostředkovatelů. 
Proč to stojí tolik peněz, vybavit si na Ukrajině papíry? No to je jenom na úplatky... Tam nejde udělat nic bez úplatku.

(pan T., ,klient"“)

(3) v roce 2004 byla méně než třetina vydaných víz přidělena za účelem zaměstnání. Většina víz byla Ukrajincům vystavena kvůli založení živnosti či kvůli účasti v právnické osobě (Cizinci..., 2005).

Udělá si živnost'ák... Oni dostávají potom snáze vízum, no a tam (v Čechách) „podnikác“.

(pan B., ,klient"“)

V roce 2005 se tento několik let trvající trend obrátil a zaměstnanecký status dnes sdílí zhruba dvě třetiny ekonomicky aktivních ukrajinských imigrantů (Datové údaje..., 2006). ${ }^{12}$ Pořád však platí, že namísto zaměstnaneckého statusu ukrajinští imigranti stále masově volí rizikovější status kvazi-živnostníků, zaměstnávaných na principech tzv. švarcsystému. Byt' jsou ve faktickém postavení zaměstnanců, formálně tento status nemají.

\section{Sociální a kulturní kapitál}

„Mezinárodní migrace je nákladný a rizikový podnik“ (Massey 1994: 1495). V tomto, pro někoho možná banálním, závěru je zkoncentrována řada nebanálních, podstatných skutečností, které pomáhají vysvětlit řadu jevů a problémů spojených s mezinárodní migrací. Např́klad důvody, proč někdo migruje, ale jeho soused žijící ve stejných ekonomických podmínkách nikoliv, proč se imigranti koncentrují ve specifických lokalitách, proč vznikají specifické organizační formy, kterým je třeba první stupeň klientského systému.

Massey považuje sociální kapitál především za zdroj omezení rizik a nákladů spojených s migrací. Podpůrné sítě imigrantovi zajišstují přístup na pracovní trh, pomáhají mu při hledání ubytování, při řešení krizových situací. Nelze opominout ani roli kulturního kapitálu, tedy potřebných informací a vědění, at' už se jedná o jazyk, místní zvyky či znalosti využitelné v rámci zaměstnání. První stupeň klientského systému proto chápu jako instituci, ve které probíhá směna ekonomického, kulturního a sociálního kapitálu. „Klienti“ jsou osoby, které těmito kapitály disponují ve vhodné struktuře pro organizování pracovní síly přistěhovalců. Zde leží i klíč pro odpověd’ na otázku, kdo se stává „klientem“.

Tak třeba přijelo pět lidí, jeden mezi nimi byl schopnější, který se líp naučil mluvit a vyznal se. A stal se předákem party. Nám řekl šéf (český zaměstnavatel) potřebujem, abyste měli jednoho šéfa, budeš to ty, protože dobře mluvíš... Pak už jsem věděl, co a jak, a udělal jsem si živnosták.

(pan S., ,klient“)

Sociální kapitál „klientů“ zahrnuje kontakty na české zaměstnavatele i sítě osob, na které se mohou za úplatu obrátit při vyřizování dokladů pro „své“ imigranty. Že jsou upláceni i čeští policisté a úředníci, naznačuje například publikace Výzkum obchodu s lidmi... (2005). I v našem výzkumu bylo uplácení několikrát zmíněno.

12 Posun může souviset se změnami legislativy, která od roku 2004 režim zaměstnávání cizinců v určitých ohledech liberalizovala. Spolehlivá analýza vysvětlující tento trend ale k dispozici není. 
Jo, jeden mi říkal: „Mám (úředníka), on veme (úplatky).“

(pan T., ,klient“")

Policie bere (úplatky) a oči nad tím vším zavírá.

(pan R., racketeer)

Pro úplatné úředníky je bezpečnější přijímat odměny od stabilních partnerů, než se jich dožadovat od stále nových, tedy neznámých tváří.

Je to o tom, že ten polda bude komunikovat jenom s tím klientem. Tam nemůže přijít někdo jiný, de o to, že když ten Ukrajinec (dělník) potřebuje zařídit něco jinýho, tak se musí obrátit na toho klienta.

(pan W., policista)

Kulturní kapitál „klientư“ zahrnuje kromě znalostí jazyka a zdejšího prostředí i znalosti českého (a ukrajinského) práva regulujícího vstup, pobyt, zaměstnávání a podnikání v České republice. Všechny předpisy dohromady vydají na objemnou knihu. Z pohledu cizince je navíc psána cizím jazykem nadvakrát: česky a ,právnicky“. „Klient“ je tedy průvodcem imigranta právním labyrintem.

Za poskytnuté služby a asistenci imigranti svým ,klientům“ platí. „Klient“ tedy směňuje svoje kontakty (sociální kapitál) a vědění (kulturní kapitál) za peníze (ekonomický kapitál). „Klient“ někdy na počátku migrace investuje do imigranta i ekonomický kapitál - v podobě půjčky, která je pak postupně splácena ze mzdy. Tato počáteční investice umořuje náklady spojené s obstaráním dokumentů, s přepravou a zajistí potřebný finanční obnos pro zaplacení ubytování a stravy předtím, než imigrant obdrží první mzdu.

Platby imigrantů za poskytnuté služby neprobíhají přímo. Mzdu čeští zaměstnavatelé předávají ,,klientům“, a ti ji pak dále předávají pracovníkům. Předtím však strhnou řadu poplatků, které nakonec činí třicet až padesát procent celkové mzdy.

My jsme mu dávali hodiny, kolik hodin jsme odpracovali, a on nám platil peníze, po hodinách. Kdo ví, možná bral sedmdesát, půl na půl.

(pan J., dělník)

Od Čecha tak sto deset a jim (dělníkům) jsem dával šedesát. A bylo jich patnáct.

(pan R., ,klient")

Z těchto peněz „klient“ hradí poplatky pro mafie, podnájmy, sociální a zdravotní pojištění, splátky za půjčky a svůj zisk. Tento výčet reprezentuje obecný balík poplatků a není nutně kompletní. Případ od případu se konkrétní složení balíku a výše poplatků liší. To, že mzdu neobdrží imigrant přímo, otevírá prostor pro podvody či vydírání. ,Klienti“ někdy vyplácejí pouze zálohy mezd a zbytek imigrant obdrží až při odjezdu domů. „Klient“ díky tomu může imigranta nutit k prodloužení pobytu či s ním i jinak manipulovat. Někdy „klienti“ platby nevyplatí vůbec. Své muže opustí nebo se jich pokusí zbavit. Pokud jsou to ilegální imigranti, může je udat cizinecké policii.

Co řekne („,klient“): ted’ tě neznám. Nahlásí ho českým orgánům: „Dejte ho pryč.“ Chce se ho zbavit, tak se ho zbaví... Nemá žádný právní ochrany a opory (dělník). Zastupitelstvo se pak musí starat. Každý den někdo. Nezná nic (dělník) - toho zaměstnavatele, možná telefonní číslo.

(pan V., diplomat) 
$\mathrm{Na}$ to, jak často je systém zprostředkovaného převodu mezd zneužíván, náš výzkum nemůže dát odpověd’. Že se nejedná o marginální jev napovídá koneckonců předchozí citát. $\mathrm{Na}$ druhou stranu by masovost takových praktik musela celý klientský systém zlikvidovat. Bez určité elementární důvěry v poctivost „klientư“ by nemohl dlouhodobě fungovat.

\section{Podmínky na trhu práce - sífová ekonomika, externalizace nákladů a disciplinace pracovní síly}

Bez ohledu na zemi původu i zemi, do níž přicestovali, sdílí pracovní migranti z chudých zemí na trhu práce zemí bohatších už po desítky let po celém světě v podstatě stejné postavení (srovnej Piore 1979, Castles a Miller 1998, Castles a Davidson 2000). ${ }^{13}$ Jsou odsunuti na tzv. sekundární trh práce, na kterém se koncentrují zaměstnání s nízkými platy, s méně výhodnými pracovními podmínkami, s nízkou společenskou prestiží. Přestože neexistují souhrnná data reprezentující celou populaci ukrajinských pracovních imigrantů, není zatím důvod domnívat se, že je tomu u nás jinak. I pokusy o kvantitativní mapování populace ukrajinských imigrantů tento všeobecný jev potvrzují, i když platnost provedených výzkumů je omezená (viz Horáková a Čerňanská 2001; Horáková, Polívka, Čerňanská a Rudolf 2001; Drbohlav a Šelepová 2001). Tento předpoklad navíc podporuje další indicie: zmíněná masovost ilegálních imigrantů a masové užívání kvazi-podnikatelského statusu. Obojí je typické pro marginalizovanou pracovní sílu. Důvody vedoucí k odsunutí ukrajinských imigrantů na sekundární trh práce jsem popsal a shrnul v jiném textu (viz Nekorjak 2005).

První stupeň klientského systému funguje v prostředí českého pracovního trhu na principu externalizace nákladů a rizik směrem od podnikatelů na pracovní sílu. Tato strategie podnikatelů je typická pro společnost sití. Keller $(2004,2001)$ vidí společnost sítí jako postupně se vynořující novou formu uspořádání sociálního světa. ${ }^{14}$ Sítové struktury se uplatňují na pracovním trhu se stále větši razancí a právě první stupeň klientského systému můžeme považovat za ideálnětypickou reprezentaci ekonomiky sítí: „,sítě jsou sestavy tvořené nezávislými uzly, mezi nimiž může být střídavě navazováno a opět rušeno spojení“ (Keller 2004: 397).

Na pracovním trhu umožňuje sítové uspořádání podnikatelům snižovat náklady sjednáváním zaměstnanců ad hoc, pouze pro daný projekt. Pracovník je bud' samostatný živnostník, nebo je najat v rámci dodávky práce od jiné firmy. Smluvní vztahy nejsou regulovány zaměstnaneckým právem ochraňujícím pracovní sílu, ale právem obchodním. Obchodní právo je založeno na principu předpokládané rovnosti zúčastněných subjektů, a tudíž nereflektuje rozdíly mezi námezdní pracovní silou a vlastníky kapitálu (Keller 2001, 2004). V českém prostředí se takovému způsobu zaměstnávání říká švarcsystém. V principu jde o přesun některých nákladů z podnikatelů na najaté pracovníky, za něž nemusí hradit zdravotní a sociální pojištění: to si platí zaměstnanci sami.

13 Výjimkou jsou vysoce kvalifikovaní odborníci, kteří získávají dobře placená zaměstnání ve svém oboru. Co do počtu je ve srovnání s klasickou pracovní migrací tzv. odliv mozků okrajovým jevem, byt' v posledních desetiletích nabývá na významu (Castles a Miller 1998).

14 Podle Kellera jde o adekvátnější pojem pro popis současných společností než jaký nabízí koncept postmodernismu. 
Klientský sytém funguje právě na principu sítí. „Klienti“ zakládají legální právnické osoby různého typu. Do svých firem imigranty najímají jako zaměstnance nebo z nich udělají formální společníky. Další možností je, že „,klient“ své dělníky vybaví živnostenským listem, sjednává jim kontrakty a dohlíží na ně, ale formálně v žádném právním vztahu nejsou. Poslední hojně využívanou možností je zaměstnávání nelegálních imigrantů. ${ }^{15}$

Půlku na půlku dává (,klient“) legální a nelegální.

(pan V., diplomat)

První stupeň klientského systému se opírá o organizačně pružné uspořádání, ve kterém se dodává českým zaměstnavatelům pracovní síla podle jejich aktuálních potřeb. Přesně podle požadavků na počet, v ideálním př́padě přesně podle kvalifikace. Podnikatelé nemusí nikoho vyhledávat. Nemusí vyjednávat s každým imigrantem individuálně. I kdyby se imigranti pohybovali na trhu práce po větších skupinkách (pracovní brigády, rodinné skupiny, kamarádské party), nenahradilo by to výhodnost využívat „klienty“. Českým podnikatelům stačí, mají-li telefonní číslo na jednoho velkého nebo několik menších „klientů“, na které se obrací jako na stabilní agenturu, která ušije kontrakt přesně na míru. Tím čeští podnikatelé snižují náklady na rekrutaci pracovní síly a externalizují je na klientský systém.

Když mu („klientovi“) někdo onemocní nebo uteče, tak musí být schopný ho nahradit... Bleskem někdo přijede z Ukrajiny, který čeká. Ten člověk doma čeká jako záloha. Až budu potřebovat, pošlu telegram, a jede.

(pan B., ,klient")

I externalizace rizik spojených s odhalením nelegálních imigrantů je přenesena na firmy „klientů“, česká firma za ně odpovědná není. Další forma externalizace nákladů z českých firem na klientský systém souvisí s dohledem a disciplinací zaměstnanců. Povolnost pracovní síly se ve světě sítí zajišt’uje na základě jednoduchého principu: bud' budou podmínky nabízeného obchodu přijaty, nebo se obchod uskuteční s někým jiným. Vztahy lze měnit pružně, kdokoliv může být rychle vyměněn. Ilegální imigranti jsou v horším postavení jen proto, že je lze ještě navíc vydírat hrozbou udání policii. V principu jsou ale jejich vztahy $\mathrm{s}$ českými zaměstnavateli v podstatě stejné jako v př́padě imigrantů s živnostenskými listy. Ti jsou chráněni jen proti vyhoštění, ale vưči českému zaměstnavateli mají stejná, tedy nulová práva. Obchodní právo umožňuje rušit smlouvy rychle - žádná výpovědní lhůta není třeba. Nespokojený pracovník může být na hodinu propuštěn a nahrazen někým ,pružnějším“.

Př́mý dohled nad pracovníky vykonává „klient“: je v jeho zájmu, aby mohl s českým podnikatelem uzavřít kontrakt i příště. Stejný tlak, vůle udržet se v pružné měnící se síti, podporuje řešení problémů v rámci samotné pracovní skupiny, př́ímo mezi dělníky.

15 „Klienti“ nabírají své pracovníky několika způsoby. Jednak je aktivně sami vyhledávají přes náborové agentury, inzercí v českém nebo ukrajinském tisku, navštěvují ukrajinské vesnice a agitují, v Čechách zajdou na dobře známá místa, jakými jsou velká nádraží, tržnice, ukrajinské konzulární úřady. Nebo se jim ohlásí imigranti sami: dostanou kontakt od známých, seženou si telefonní číslo, na stavbě pozorují, kdo se mezi Ukrajinci pohybuje v čistém oblečení a nevypadá jako dělník apod. 
Oni si taky vyřizují mezi sebou, když někdo v té partě jim nesedí, dělá problémy a jim by hrozila ztráta práce.

(pan B., ,klient")

Měl jsem taky problémy, občas se vyskytnou. Já to neřešim. Říkaj: „Klid šéfe, zítra bude pořádek.“ No ten (problémový) chodí druhej den po stavbě, má oteklou palici, ale je pořádek. Oni si to vyřizujou sami. Oni věděj, že já bych volal klientovi, a to už oni nepotřebujou.

(pan K., český zaměstnavatel)

Tvrdším prostředkem disciplinace zaměstnanců ze strany „,klientư“ je vyhrožování násilím. Akt násilí mají na starost specializovaní bijci z řad mafie. Takový postup volí někteří „klienti“ v př́ípadě, když jim hrozí nepředvídaný odchod zaměstnanců. Zaměstnanci bud’ chtějí odejít k jinému „klientovi“, nebo se chtějí z klientského systému vyvázat a uplatnit se na českém pracovním trhu samostatně, anebo se chtějí vrátit domů. Pro „klienta“ to znamená (zejména když má dostatek zakázek a málo pracovníků), že je ohrožen jeho vlastní zisk, ale také jeho pověst spolehlivého dodavatele pracovní síly. Druhým nedobrovolným způsobem připoutání pracovníka ke „klientovi“ je trvalé zadržení pasu. Pasy musí „klient“ odebrat, pokud má na úřadech vyřizovat potřebná povolení, takže prevence proti takovému triku je obtížná.

Přijde (dělník) a nikoho nezná. Klient mu sebere pas. Na ubytovnu ho přivede a řekne mu: „Tady budeš bydlet. A tady budeš chodit do práce.“ (...) Doklady si od něj vezme. Aby nezmizel. Kam půjde bez dokladů?

(pan R., racketeer)

Existuje ještě třetí způsob připoutání a vynucení poslušnosti. „Klient“ přislíbí přeměnit turistické vízum na vízum dlouhodobé, ale po uplynutí termínu imigrant zjistí, že žádné vízum nemá. Stane se nedobrovolně ilegálním imigrantem. Má jedinou volbu: bud' odjede domů, nebo zůstane a pracuje načerno. $\mathrm{V}$ tom případě je ale vydíratelný na základě už zmíněného udání cizinecké polici.

Nakolik jsou podobné triky běžné, není možné v rámci kvalitativního výzkumu určit. Zřejmě nebudou vzácné; na druhou stranu ani nemůžou být samozřejmou součástí klientského systému, který by se musel za takových podmínek fungování zhroutit, protože imigranti by volili jiný způsob př́stupu na pracovní trh. Imigranti o nich hovoří jako o nenormálních praktikách, nepovažují je za legitimní součást klientského systému.

Princip externalizace nákladů nevyužívají pouze čeští podnikatelé. Z takovéhoto uspořádání částečně profituje i zbytek české společnosti: formou odvedených daní, spotřebovaného materiálu, vykonané práce. Český stát omezením př́stupu k zaměstnaneckému statusu externalizuje náklady spojené s ,,pojistnými událostmi“: důchod, úraz a nemoc. V př́ípadě neúspěchu (nezaměstnanost) odjede imigrant domů a nezatěžuje státní pokladnu. I přípravu na povolání a „neproduktivně“ strávené dětství cizinec prožije doma: česká státní pokladna nenese žádné náklady spojené s výchovou a př́ípravou ukrajinské pracovní síly. 


\section{Vznik druhého stupně klientského systému, služby a vzłahy $\mathbf{v}$ jeho rámci}

Druhý stupeň klientského systému je obtížně mapovatelný. Malá ochota respondentů o něm hovořit je pochopitelná. I imigranti, kteří v klientském systému nepracovali, či jím prošli, ale v době rozhovorů v něm už neparticipovali, k otázce zapojení mafií běžně přistupovali jako k tématu, o kterém není slušné hovořit. Kromě morálních zábran byly patrné i obavy ze stigmatizace. A to nejen z poškození osobní image, ale i ze stigmatizace ukrajinských imigrantů jako celku. V neposlední řadě byly patrné i utilitárních důvody mlčení a mlžení, které lze chápat jako obranu jedné z funkčních strategií přístupu na český pracovní trh. Přesto část respondentů hovořila otevřeně a byla ochotna sdílet své zážitky, informace a pohledy na tuto problematiku. ${ }^{16}$

Popis druhého stupně klientského systému zaměřím na dvě témata, která mi poznatky z výzkumu dovolují interpretovat: na základní důvody jeho ustavení a na problematiku vztahů mezi mafií a ,klienty“.

Pro ustavení prvního stupně klientského systému jsem identifikoval jako tři nejdůležitější okolnosti (a) formální postavení cizinců, (b) roli sociálního a kulturního kapitálu a (c) podmínky na trhu práce. Pro vznik druhého stupně, a tedy pro uplatnění mafíi v klientském systému, nabízím dvě vzájemně se doplňující vysvětlení. První se vztahuje na dlouhou historickou tradici organizovaného zločinu v zemích bývalého Sovětského svazu a na jejich specifickou činnost: tzv. „ochranu“ neboli racket. Tato forma kořistění byla v průběhu devadesátých let přenesena do Česka a uplatněna v prostředí pracovní migrace. Druhým zdrojem vysvětlení je permanentní selhávání jednoho ze základních poslání moderního státu: ochrana obyvatel proti násilí.

\section{Racket a mafie: historické kořeny}

Podobně jako Jan Černík (2005) jsem došel k závěru, že kořeny zapojení mafií v ukrajinské pracovní migraci můžeme nalézt v organizování nelegálních a pololegálních ekonomických aktivit v Sovětském svazu. Formy generování zisku z pracovní migrace, které ukrajinská mafie v klientském systému uplatňuje, nevznikly až v Česku, ale byly do zdejšího prostředí vneseny jako určitý ustavený typ činnosti ukrajinského organizovaného zločinu. ${ }^{17}$

Intenzivní činnost mafií na území bývalého Sovětského svazu není jevem posledních patnácti let. V průběhu sovětského režimu se struktury organizovaného zločinu obohatily o nová spojenectví se státním aparátem. Vznikaly vzájemně si konkurující skupiny, které se často diferencovaly nejen podle regionů, ale právě podle příslušnosti jejich členů k různým složkám státní moci.

16 Informace pocházejí zejména od tř́i „klientư“ a jednoho člena mafie. Imigranti-zaměstnanci komplexní přehled o druhém stupni v podstatě neměli a podávali spíše kusé informace.

17 Jan Černík (2005) publikoval ještě zprávu Klientský systém jako quasi-feudalismus v Česku. Jeho závěry se shodují s mými také v odkazu na důležitou roli flexibility v celém systému ukrajinské pracovní migrace, $\mathrm{v}$ upozornění na zásadní hodnotu sociálního kapitálu pro ustavení funkce „,klientư“ a v určení výše sumy placené za jednoho imigranta. Čtenáře proto odkazuji také na práce zmíněného autora a dále na studii Výzkum obchodu s lidmi především za účelem nucené práce (2005). Vzájemné kritické porovnání výsledků realizovaných výzkumů si zaslouží samostatný článek. 
V Sovětském svazu se stalo vybírání poplatků za ochranu, tzv. racket, běžnou činností nejpozději během éry přestavby, ale nejspíše už mnohem dř́ve, za brežněvovského období. Odborníci se však shodují na jednom: že činnost těchto skupin byla významně posílena $\mathrm{v}$ období Gorbačovovy perestrojky, která pootevřela větší prostor podnikavosti a byznysu. Začleněním nomenklatury a bezpečnostních složek do organizovaného zločinu získaly tyto struktury př́mo pohádkové možnosti. Klienti mafie se rekrutovali ze světa šedé ekonomiky, obchodu se sexem, ale směňoval se i kariérní postup. Patroni ze státního aparátu poskytovali svým klientům politicky zastř̌šenou ochranu. Ekonomika rozvinutá v klientských vztazích často zprostředkovávala a ochraňovala činnosti, které socialistický stát vytlačil za hranice zákona nebo které byly ,,v zemi, kde zítra znamená včera“ obtížně dostupné. Moc, a tedy i role mafií v postsovětských zemích byla opět výrazně posílena po politickém převratu v roce 1991. Souviselo to s obrovskými přesuny majetků ze státních do soukromých rukou, s oslabením moci státu $\mathrm{v}$ oblasti zajištění bezpečnosti, která byla provázena vzrůstem významu privátně zajišt'ované dobrovolné i vnucené ochrany - racketu (McFaul 1995, Radaev 2000). Postsovětský ukrajinský stát se zároveň nevzdal přebujelé regulace společnosti, takže klientelismus státního aparátu na svém významu rozhodně neztratil (Markovskaya, Pridemore a Nakajima 2003).

Sovětský organizovaný zločin do značné míry využil a posléze modifikoval praktiky svých italských ,učitelů“. Racket má svůj původ na Sicílii. Zajišt’oval peníze pro podporu politického kandidáta, kterého si mafie vyhlédla. Později se proměnil ve výběr peněz za ochranu. Tomu, kdo nechtěl platit, mafie uspořádala před domem nebo podnikem racket varovný a hlučný dýchánek. Toto slovo se nakonec stalo synonymem pro vydírání jako takové a obsáhlo řadu dalších praktik (Červinka 1991: 321). Nakonec i uplatnění racketu za hranicemi vlastního státu a jeho přenesení do prostředí pracovní migrace bylo poprvé realizováno Cosa Nostrou ve Spojených státech v dobách masového príichodu italských imigrantů, tedy dávno před rozvinutím ukrajinské pracovní migrace v devadesátých letech (tamtéž: 320).

Mafie a výběr poplatků za vnucenou ochranu mají na Ukrajině, jako dědictví komunistického režimu, dlouhou tradici. Tradice ale sama o sobě ještě pro vysvětlení výběru poplatků za ochranu mezi ukrajinskými imigranty v České republice nestačí. Osvětluje pouze dobu a místo vzniku jedné z více možných strategií generování zisku organizovaným zločinem. $\mathrm{Na}$ otázku, proč se tato strategie mohla uplatnit v Česku, jsem našel základní odpověd' v určité formě sociálního vyloučení ukrajinských imigrantů.

\section{Částečně odstátněný prostor?}

Při analýzách postavení cizinců se výzkumy často soustředí na to, která formální oprávnění jsou jim upírána, popř́ípadě se mapují neformální projevy xenofobie a diskriminace. Ukrajinců se však týká ještě další forma vyloučení ze služeb moderního státu: $\mathrm{z}$ ochrany obyvatel proti násilí.

$\mathrm{V}$ těch ranějších dobách... já jsem to nahlásil, kdy přijdou (mafie)... Tehdy na to oni (policie) kašlali. (pan. R., ,klient“)

Historicky se ochrana před rizikem a ohrožením řešila koalicemi s mocensky asymetrickým nebo symetrickým uspořádání vztahů. Klientela je typem prvním, typem druhým byly svépomocné organizace $\mathrm{v}$ principu rovných individuí: například cechy či městská společenství vůbec. Nástup novověku a později modernity byl provázen postupným rozbíjením vazeb, které 
zajišt'ovaly sociální solidaritu a ochranu v tradiční společnosti. Stát začal přebírat ty funkce, které poskytovalo dříve prríbuzenstvo, církev, cechy, vesnická komunita, feudální svazky (Keller 2005: 91). Modernizaci a vznik národního státu lze tedy také popsat optikou koncentrace obou typů zvládání rizik a ohrožení v jediné instituci: v moderním národním státě, provázené delegitimizací klientelismu. Stát se stal generalizovaným patronem i institucí neosobního zprostředkování vzájemné solidarity a ochrany formálně rovných občanů. Přesto tradiční instituce klientelismu nezmizela. Daří se mu tam, kde nejsou žádané služby běžně dostupné, ale klientela dokáže jejich distribuci zajistit. A rozvíjí se také tam, kde je státní moc slabá. V případě ochrany před fyzickým násilím je to „svépomocná iniciativa“, která řeší problém ,jak zajistit méně mocným ochranu a bezpečí při neexistenci organizace specializované na tyto cíle“ (Keller 1997: 72). ${ }^{18}$

I v př́ípadě ukrajinské migrace se setkáváme s problémem veřejné přístupnosti ke statkům a službám, které má zajišt'ovat moderní stát. V nechráněném prostředí, v prostoru, který stát nechal do značné míry napospas sobě samému, se prosadilo ,právo silnějšího“, tedy ozbrojených skupin, pro něž je výkon násilí jednou z obvyklých činností:

Policajti ř́kali: „To je mezi nima.“ Ty počátky, to tady tak bylo. „,o, to je mezi nima, to nemá cenu.“ (pan B., ,klient")

Omezením práv imigrantů na ochranu před násilím český stát otevřel příležitost „,svépomocné iniciativě“ mafií, které nechráněný prostor ovládly a využily tak neprrímo nabízenou př́ležitost ke svému prospěchu. Nechci tvrdit, že to byla pouze a jen tato prríčina, která institucionalizovala činnost mafií v prostředí ukrajinské pracovní migrace, považuji ji však za klíčovou. Ustavení a následné posílení role mafií souvisí také s ilegálním statusem významného počtu imigrantů, s administrativními regulacemi a s dočasností pobytu imigrantů.

Ilegalita imigrantů ztěžuje možnost vzniklý problém řešit za pomoci české policie, jež je v takovém př́ípadě jak potenciálním partnerem, tak i hrozbou pro firmy ,klientů“, které ilegální migranty běžně zaměstnávají.

Administrativní regulace omezují svobodný př́stup cizinců na pracovní trh, a tak utváří poptávku po standardních (poradenství, asistence), ale i nestandardních (korupce a potřebné známosti) službách, které dokáže mafie efektivně zajistit.

Dočasnost pobytu většiny imigrantů znamená, že se cizinec jednoho dne vrátí domů. Pokud se postaví na odpor zavedenému pořádku, či se dokonce pokusí o spolupráci s českou policií, může potenciálně uspět. Ale po odjezdu z Česka se vrací do prostředí, které má pod kontrolou lokální větev mafie. Mafie tedy disponují vysokým vyděračským potenciálem, který pracovní migranty a „klienty“ účinně disciplinuje. V obvyklém spojení s ukrajinskou státní správou se její potence navíc zvyšuje:

Budeš hodný. Hlavně když ti to přijdou ještě vysvětlit třeba s nějakým blbcem z (ukrajinské) policie, protože ten propletenec tam je.

(pan S., ,klient"“)

18 Keller na tento jev poukazuje v jiném kontextu než je mezinárodní migrace. Popisuje jej jako jeden z typů sociability, který prokazuje vitalitu i uvnitř moderních institucí, v jejichž rámci ale není považován za legitimní (Keller 1997, 2004, 2005). 
Imigrant navíc nenese odpovědnost jen sám za sebe. Terčem zastrašování je i jeho rodina, která se tak stává vždy latentním rukojmím. Je proto obtížné vyhnout se nátlaku pomocí trvalé emigrace či dočasného ukrývání.

\section{Vztahy mezi mafií a „klienty“}

S několikaletým zpožděním se problematika klientského systému stala předmětem zájmu státní správy a podle vládních dokumentů lze soudit, že nyní bude oblastí cílené intervence (viz Národní strategie..., 2005, Potírání obchodu..., 2006). V těchto koncepčních materiálech je klientský systém hodnocen jako kriminální mašinerie. Poukázal jsem na to, že klientský systém je složen ze dvou částí, které se v daných podmínkách propojily ve fungující uspořádání, že však každý z obou stupňů má odlišné zdroje svého vzniku.

Mým cílem je poukázat na ambivalentní, nejednoznačný vztah mezi „klienty“ a mafií, který nelze paušálně hodnotit jako výhodný/nevýhodný či zcela dobrovolný/nedobrovolný. Následující část textu se zabývá službami, které mafie „klientům“ poskytují, a v závěru statě předkládám typologii „klientư“ podle jejich vztahu k organizovanému zločinu.

\section{Služby ekonomického charakteru a administrativní servis}

Přestože se mafie ,klientům“ běžně pod pohrůžkou násilí vnucují, nabízejí určité protislužby, ze kterých má „,klient“ prospěch - pokud jich využije. Těmito úsluhami ale mafie hájí především svůj ekonomický zájem. Prosperující „,klient“ znamená výtěžek. Nejedná se o blahosklonnou pomoc tradičního patrona svému klientovi. Služby mafie dělím na dvě skupiny, na ekonomicko-administrativní služby a zajištování bezpečnosti Do první kategorie služeb patří (1) půjčky, (2) regulace konkurence a (3) administrativní servis.

(1) Tak jako poskytují půjčky svým pracovníkům ,klienti“, i mafie je ochotná investovat kapitál do „klienta“, pokud se dostane do finanční tísně.

(2) Úspěšnost „klienta“ už dnes neodvisí pouze od jeho individuální schopnosti obstát v konkurenci:

Oni sami (mafie) mají zájem to regulovat.

(pan T., ,klient")

Mafie postupně ovládly klientský systém natolik, že jsou schopny ovlivňovat počty „klientů“ na daném území, a tím konkurenci regulovat podle vlastního uvážení.

(3) Propojení mafií se státními úředníky zajišt’uje „klientům“ administrativní servis.

Co, nemáš doklady? Mafie ti vybaví za svoje peníze doklady. Můžeš se s nimi rychle dohodnout, všude mají známé.

(pan R., racketeer)

„Klienti“ mají možnost požádat mafie o pomoc při obstarávání dokumentů pro imigranty a zajistit tak stabilní prŕísun pracovní síly. ${ }^{19}$

19 Z etických důvodů nemohu bohužel jednu z nejzajímavějších pasáží ze svých rozhovorů zveřejnit. 


\section{Zajištění bezpečnosti: tautologická legitimizace organizovaného zločinu}

Do druhé kategorie služeb patř́ tzv. ochrana neboli racket. Poplatek za ochranu, kterou fakticky nelze odmítnout, je stabilní a činí zhruba tisíc korun za každého imigranta, kterého „,klient“ zaměstnává. ${ }^{20}$ Existence prvního stupně klientského systému výběr poplatků za vnucenou ochranu zefektivňuje. Mafie nemusí obcházet a přesvědčovat imigranty individuálně, primárně kontaktuje „klienty“. Imigrant nemusí tedy do styku s mafií přijít, vydírání je „,zkultivováno“, protože poplatek je odnímán dělníkovi automaticky, ještě před vyplacením zbytku jeho mzdy. Nátlak na dělníky nemá tedy primárně charakter fyzického násilí. Má především formu potenciálního vyloučení z českého trhu práce - ze sítí klientského systému, který k němu zajišt’uje snadný přistup.

Tautologickou legitimizací zmíněnou v podtitulku mám na mysli to, že se mafie staly př́íčinou i řešením problémů spojených s násilím v „odstátněném prostoru“. Přejaly roli policie a chrání své „klienty“ proti vydírání konkurenty. Ty lze rozdělit na dvě kategorie: mafiánské a ne-mafiánské.

Mafie není monolitickou organizací. Na našem území operují skupiny z různých regionů Ukrajiny, např́íklad známá luhanská brigáda, mukačevská brigáda, kijevská brigáda a další. A kromě ukrajinských mafí zde působí i organizace pocházející z jiných států: Albánie, Ruska, Čečenska, Číny ad. (Zpráva o situaci..., 2002).

Dohlížel jsem, aby je nikdo neobtěžoval. Aby za nimi nepřišli a peníze jim nebrali Albánci nebo naši mafiáni.

(pan R., racketeer)

Ne-mafiánští konkurenti jsou bud' jednotlivci nebo zločinecké bandy stojící mimo struktury mafií. Nejenže využívají státem málo chráněný prostor, ale také využívají pověsti, image, kterou mafie má. Mezi Ukrajinci kolují různé historky. I ten, kdo se do styku s mafiemi nedostal, může znát řadu drsných př́běhů. Např́klad pan D., který pracuje v české firmě a nikdy nebyl součástí klientského systému, na základě takových historek shrnuje v nadsázce úděl ukrajinského dělníka takto:

Životnost Ukrajince je tak do třiceti let, pak plave jeho mrtvola v nějaký stoce.

Latentní funkcí „,historek z podsvětí““ je socializace imigrantů do vztahů respektu a podřízenosti vůči mafiánům. Tito neregulérní výběrčí poplatků nemusí nutně sahat k násilí (byt' se to nevylučuje) a pokouší se okrádat „klienty“ či př́mo imigranty jen na základě toho, že je systém racketu pevně institucionalizovaný.

Řeknou si: „Hele, my zítra budeme mafie.“ Koupí si vyskakovací nožíky a hodí na sebe kvádro. Vyrukují a cvaknou nožíkem a řeknou: „Budeš nám platit.“

(pan I., dělník)

Popisuje právě propojení mafií a státních úředníků při zajištování jednoho z potřebných povolení pro imigranty.

20 Proč je poplatek na našem území v podstatě všude stejný? Bud' to znamená, že jsou mafie schopné se mezi sebou dohodnout, nebo že konkurenční skupiny jsou zastřešeny mocnější strukturou, která je schopna si konsensus vynutit (viz také Černík 2005). 
Sama mafie na tyto potulné loupeživé rytíře prríliš nedoplácí. Ráda se staví do role ochránce „klientů“ před divokými přepady. Výhodnost je oboustranná.

V marasmu odstátněného prostoru se zvýšeným rizikem násilí nelze upřít mafiím jeden pozitivní přínos. Mafie vybírá své poplatky kultivovaně, podřídí-li se objekty jejího zájmu jejím pravidlům. Násilí není třeba cyklicky opakovat. Ani výše poplatků není pro „klienty“ a pracovníky zničující. Její chování do jisté míry připomíná chování státu, který už přistoupil na pravidelný výběr daní s jasně stanovenými taxami a který si nárokuje monopol na toto zdaňování i na používání násilí vůči svým klientům.

\section{Typy „klientن̊“ podle vztahu k mafii}

Zapojení organizovaného zločinu do ukrajinské pracovní migrace přes osobu „klienta“ je jednou z příčin, proč bývá v českém prostředí „,klient“ běžně chápán jako integrální součást mafie.

Ti klienti jsou z tý mafie. Nějaký ty spodky, který drží ty lidi, to jako určitě... Je nižší spodní vrstva tý mafie, je to nižší článek.

(pan S., policista)

Podobná paušální hodnocení „,klientư“ jsou zjednodušující, ale o „,klientech“ nelze tvrdit ani pravý opak. Vztah „klientů“ a organizovaného zločinu není jednoznačný. „Klienti“ nejsou homogenní skupinou, ale diferencovanou vrstvou lišící se nejen podle ekonomické úspěšnosti a velikosti firem, ale i podle vztahu $\mathrm{k}$ mafiím. Mezi „,klienty“ najdeme bezúhonné podnikatele, podnikavce i vyložené podvodníky. Z hlediska jejich vztahu ke zločinu jsem na základě svého výzkumu vytvořil následující typologii.

\section{(A) Pasivní}

„Podstatou každého klientského vztahu je nerovný, avšak reciproční vztah mezi patronem a jeho klienty“ (Keller 1997: 68). Typickou protislužbou patrona je vojenská, právní či intervenční ochrana u orgánů správy, i podpora ekonomická, zejména v kritických situacích (ibid.). To ve vztahu mezi mafií a těmito „klienty“ potenciálně platí, pasivní typ „klienta“ ovšem nesplňuje jeden podstatný znak tradiční klientely. V tradičním klientském vztahu klienti svého patrona všemožně podporují na bázi loajality a věrnosti, vztah je dobrovolný. Protože byl ale „pasivním“ tento vztah vnucen, můžeme jej považovat za kvazi-klientský. Navíc pasivní „,klienti“ speciálního ekonomicko-administrativního servisu mafie nevyužívají, pouze splácí vnucené poplatky.

\section{(B) Pragmatici}

Pragmatici s předchozím typem sdílí nedobrovolnost vnuceného svazku s mafií. Pragmatik se však přizpůsobuje dané situaci a pokouší se ve svůj prospěch využít některé nabízené výhody. Zejména v oblasti obstarávání administrativních povolení či peněžních půjček.

\section{(C) Bezohlední}

Ani „,bezohlední“ nejsou součástí mafiánských struktur, ale jejich praktiky lze označit za protizákonné a v tomto smyslu patří do světa zločinu, nikoliv však organizovaného. Jsou to 
„klienti“, kteří se snaží maximálně profitovat ze své dominantní situace a bezohledně zacházejí se svými krajany. Nevyplácí mzdy či je nutí pracovat proti jejich vůli. Vydírají je pak pod hrozbou udání nebo fyzického násilí. Od předchozích typů se liší právě tím, že jsou naprosto bez skrupulí. Byt' ani pragmatici a pasivní nejsou členy Armády spásy a snaží se vydělat maximum prostředků využíváním práce svých krajanů, neodírají imigranty za hranice nepsaných dohod, které jsou imigrantům dopředu známy.

\section{(D) Mafiáni}

Část „klientư“ př́mo pochází z prostředí organizovaného zločinu. Bud’ mafie sama zorganizuje „klientskou“ firmu, nebo do hotového podniku dosadí svého člověka a firmu zcela ovládne.

Mafie dala ke klientovi pomocníka. Svého. A tak za půl roku, za rok jde klient do háje. Pro dělníka to není žádný rozdíl. Tomu je dobře, protože mafie platí.

$$
\text { (pan R., ,klient“) }
$$

Třetí možností je postupné zapojení „klienta“ do struktur organizovaného zločinu. Jeden z mých respondentů takovou proměnou mezi několika typy „klienta“ prošel. Z pragmatika se časem stal bezohledný „klient“ a nakonec se začlenil do mafie. Navržené kategorie je proto třeba brát jako typy vztahů, které se mohou měnit.

Na otázku, nakolik jsou jednotlivé typy proporčně zastoupeny, nemůže dát kvalitativní výzkum spolehlivou odpověd'. A v tomto specifickém případě ji asi nemůže poskytnout ani výzkum kvantitativní. Dovolím si ale drobnou úvahu. Označování slovem klient by nemělo opodstatnění, pokud by „klienty“ byly převážně osoby z prostředí organizovaného zločinu. Slovo klient označuje někoho, kdo je instituci či osobě v daném svazku vnější.

\section{Shrnutí}

Poukázali jsme na to, že tzv. klientský systém tvoří dva základní stupně a tři typy aktérů. První stupeň klientského systému vznikal v reakci na podmínky trhu práce, českou legislativu a její provádění v praxi. Také odpovídá na rizika a kapitálovou nákladnost mezinárodní migrace a nabízí řešení ve formě zprostředkování potřebného vědění, kontaktů, služeb i peněz. Ukrajinci na trhu práce nabízejí vysoce flexibilní pracovní sílu. „Klienti“ pak přistoupili na sítové uspořádání ekonomických vztahů. Obě strategie se doplňují a pro české podnikatele znamenají externalizaci nákladů, jež zvyšuje atraktivitu takto organizované pracovní síly.

Druhý stupeň klientského systému vznikl historicky později napojením ukrajinského organizovaného zločinu. Mafie z prvního stupně odvádí část peněz, za než nabízí tzv. ochranu neboli racket. Jedná se o ochranu před konkurenčními vyděrači a jinými mafiánskými skupinami. Tak existence mafíi legitimizuje sama sebe. Nabízí však i další služby: poskytuje půjčky, investice, obstarává doklady a prevenci proti zásahům úřadů pomocí úplatků.

Mafie provozovala racket už za dob sovětské éry. Tento model vydělávání peněz byl pak přenesen do České republiky. V prostředí imigrantů se mohl snadno uchytit díky praktickému - nikoliv formálnímu - vyloučení těchto obyvatel z práva na ochranu před násilím, které český stát zajištuje primárně svým klientům, tedy svým občanům. 
Mafie nemusí vykonávat nátlak na imigranty ani přímo, ani individuálně. Náklady spojené s výběrem peněz přenesla do značné míry na „klienty“, kteří poplatky za zaměstnávané imigranty zaplatí. Došlo tedy postupně k posunu role „,klienta“. K úloze zprostředkovatele mezi imigranty, trhem práce a administrativním aparátem mu prribyla role zprostředkovatele mezi imigranty a mafíi. Nátlak na dělníky má primárně povahu exkluze z klientského systému, potenciálně i z českého pracovního trhu. Použití násilí samozřejmě není vyloučeno a je využíváno, ale nemá povahu systematického, cyklického teroru.

Podle Jana Kellera jsou klientela a sít’ové uspořádání pracovních poměrů typické pro de-etatizovaný prostor, ve kterém má hlavní vliv soukromý zájem a soukromá moc. Pro ukrajinský klientský systém je charakteristické obojí: jak ekonomika sítí, tak klientela. Můžeme tedy hovořit o syndromu chybějícího státu a klientský systém chápat jako amalgám modernity $\mathrm{s}$ institucemi tradiční společnosti.

Na postavení ukrajinského imigranta vydělává „,klient“, mafie, český podnikatel, leckterý úplatný úředník (ukrajinský i český) a česká i ukrajinská státní pokladna. ${ }^{21}$ Přesto se imigrantovi vyplatí část vlastního zisku těmto aktérům a institucím podstoupit, přesto je pro něj i za takových podmínek stále výhodné v zahraničí pracovat. Je ale otázkou, zda tato relativní výhodnost může legitimizovat současný stav systematické marginalizace pracovních imigrantů na trhu práce a několikastupňového vykořist'ování ze strany některých českých zaměstnavatelů, mafíi a nesolidních ,klientů“. I z hlediska hodnot zakotvených v našich vlastních zákonech a politických koncepcích české vlády lze stávající situaci označit za neetickou. ${ }^{22}$

\section{Poděkování}

Za podporu a připomínky při sepisování statě bych chtěl poděkovat Mikuláši Nekorjakovi a Ivo Možnému. Děkuji i svým recenzentům za jejich poznámky, které mi pomohly více reflektovat sepsaný text a lépe promyslet některé aspekty a témata dalšího výzkumu.

\section{Literatura}

Castles, S., Davidson, A. 2000. Citizenship and Migration: Globalization and the Politics of Belonging. London: MacMillan Press.

Castles, S., Miller, M.J. 1998. The Age of Migration: International Population Movements in the Modern World. New York: The Guilford Press.

Cizinci $v$ České republice. 2005. Praha: Český statistický úřad.

Černík, J.; Hulíková, T.; Vintr, V.; Krištof, R. 2005. Pilotní výzkum v prostředí obchodu s lidmi na území České republiky. Praha: Mezinárodní organizace pro migraci.

21 Podle Keryk (2004) jsou ukrajinští imigranti největšími investory zahraničního kapitálu a objem dovezených peněz ze zahraničí (nejen z Česka) překračuje ukrajinský státní rozpočet. Výdělek podnikatelů je potenciálně také velmi vysoký. Jak rríká podnikatel pan K.: „Já měl na Ukrajinci ušetřených šedesát až osmdesát korun. Za každou hodinu.““

22 Viz např́íklad Národni strategie boje proti obchodování s lidmi (2005) nebo dokument Zásady koncepce integrace cizinců na územi $\check{C} R$ (1999), který je podkladem české imigrační politiky. 
Červinka, S. 1991. „Doslov. “ In M. Puzo Kmotr. Praha: Svoboda.

Drbohlav, D.; Janská, M.; Šelepová, P. 2001. „Ukrajinská komunita v České republice.“ In T. Šišková (ed.) Menšiny a migranti v České republice: My a oni v multikulturní společnosti 21. století. Praha: Portál, s. 89-98.

Horáková, M.; Čerňanská, D. 2001. Zaměstnáváni cizinců v České republice: II. část. Závěrečná zpráva z empirického šetření. Praha: Výzkumný ústav práce a sociálních věcí.

Horáková, M.; Polívka, M.; Čerňanská, D.; Rudolf, V. 2001. Nelegální zaměstnávání cizinců jako prekážka v jejich integraci na trhu práce. Část II. Výsledky empirického šetření na úradech práce v České republice. Praha:Výzkumný ústav práce a sociálních věcí.

Keller, J. 1997. Úvod do sociologie. Praha: Sociologické nakladatelství.

Keller, J. 2001. Politika s ručením omezením: Proměny moci na prahu 21. století. Praha: ELK.

Keller, J. 2004. Dějiny klasické sociologie. Praha: Sociologické nakladatelství.

Keller, J. 2005. Soumrak sociálního státu. Praha: Sociologické nakladatelství.

Leschtina, J. 2005. „O zapadlých očích nevolníků z Ukrajiny.“ Vikend: magazín Hospodár̆ských novin, 18. 11.

Markovskaya, A; Pridemore, A.; Nakajima, C. 2003. „Laws Without Teeth: An Overview of the Problems Associated with Corruption in Ukraine." Crime, Law and Social Change, 39/2: 193-213.

Massey, D. S.; Goldring, L.; Durand, J. 1994. „Continuities in Transnational Migration: An Analysis of Nineteen Mexican Communities. “ American Journal of Sociology, 99/6: 1492-1533.

McFaul, M. 1995. „State Power, Institutional Power, and Politics of Privatization in Russia.“ World Politics, 47/2: 210-243.

Morris, L. 2002. Managing Migration: Civic Stratification and Migrants Rights. London: Routledge.

Národni strategie boje proti obchodování s lidmi (pro obdobi 2005-2007). 2005. Praha: Ministerstvo vnitra.

Nekorjak, Michal. 2005. „Pracovní migrace Ukrajinců do České republiky.“ In L. Hučko (ed.) Duchovní a kulturně společenská podpora integrace národnostních menšin. Praha: Apoštolský exarchát Řeckokatolické církve v České republice, s. 21-36.

Piore, M. J. 1979. Birds of Passage. Migrant Labour in Industrial Societies. Cambridge: Cambridge University Press.

Radaev, V. 2000. „The Role of Violence in Russian Business Relations.“ Russian Social Science Review, 41/5: 39-66.

Sirovátka, T. 1997. Marginalizace na pracovním trhu: př́činy diskvalifikace a selhávání pracovní sily. Brno: Masarykova univerzita.

Výzkum obchodu s lidmi především za účelem nucené práce. 2005. Havírov: Intermundia.

Zilynskyj B.; Kočík, R. 2001. „Ukrajinci v ČR.“ In T. Šišková (ed.) Menšiny a migranti v České republice: My a oni v multikulturní společnosti 21. století. Praha: Portál, s. 81-88.

Zilynskyj, B. 1995. Ukrajinci v Čechách a na Moravě (1894) 1917 - (1945) 1994. Praha: $\mathrm{X}$-Egem.

Zpráva o situaci národnostních menšin v České republice za rok 2003. 2004. Praha: Úřad vlády ČR: Sekretariát Rady vlády pro národnostní menšiny. 
Zpráva o situaci v oblasti veřejného pořádku a vnitřni bezpečnosti na územi České republiky v roce 2002. 2002. Praha: Ministerstvo vnitra.

Internetové zdroje

Černík, J. 2005. Klientský systém jako quasi-feudalismus v Česku. Migraceonline [cit. 14. 1. 2005]. Dostupný z: $<\mathrm{http}: / / w w w . m i g r a c e o n l i n e . c z /$ studie_f.shtml? $\mathrm{x}=218348>$

Datové údaje - ekonomická aktivita. 2006. Cizinci v České republice [cit. 14. 4. 2006]. Dostupný z: $<$ http://www.czso.cz/ciz/cizinci.nsf/i/datove_udaje_ekonomicka_aktivita $>$

Keryk, M. 2004. „Labour Migrant: Our Savior or Betrayer? Ukrainian Discussions Concerning Labour Migration.“ Migraceonline [cit. 31. 10. 2004]. Dostupný z: <http: //www.migraceonline.cz/clanky f.shtml? $\mathrm{x}=203474>$

Leontiyeva, Y. 2005. „Ukrajinci v ČR.“ Socioweb [cit. 20. 12. 2005]. Dostupný z: <http: //www.socioweb.cz/index.php3?disp=aktuality>

Náš vztah k jiným národi̊m a národnostem. 2005. Centrum pro výzkum veřejného mínění [cit. 25. 3. 2005]. Dostupný z: <http://www.cvvm.cas.cz/upl/zpravy/100459s_ov50325.pdf >

Potírání obchodu s lidmi v ČR a možnosti optimalizace bezpečnostní politiky státu (tisková zpráva a analýza). 2006. Ministerstvo vnitra ČR [cit. 23. 5. 2006]. Dostupný z: $<$ http: //www.mvcr.cz/zpravy/2006/obchod_lidi.html>

Zásady koncepce integrace cizinců na území ČR. 1999. Dostupný z: <http://racek.vlada.cz/ usneseni/usneseni_test.nsf/usneseni/usneseni_test.nsf/7A47E9A11A42744CC12567EE0 04C6D1D?opendocument>

\section{Autor}

Michal Nekorjak je výzkumným pracovníkem Institutu pro výzkum integrace a reprodukce společnosti na Fakultě sociálních studií Masarykovy univerzity. Vystudoval sociologii na téže fakultě, kde v současné době pokračuje v postgraduálním studiu. Zabývá se problematikou sociální exkluze a mezinárodní migrací. Kontakt: nekorjak@fss.muni.cz 